Drug Discov Today Dis Mech. 2007 ; 4(4): 293-300. doi:10.1016/j.ddmec.2008.05.004.

\title{
Inheritance of Colorectal Cancer
}

\author{
Randall Burt, M.D. \\ Huntsman Cancer Institute and Department of Medicine, University of Utah, Salt Lake City, Utah
}

\begin{abstract}
Inheritance is involved in up to one third of colon cancer cases. Highly penetrant inherited syndromes account for approximately $3 \%$, while more common, but less penetrant inherited factors play a role in the remainder. Approaches to recognizing each of these categories and syndromes, using genetic testing for diagnosis where indicated, and accomplishing proper cancer screening and surveillance will be outlined in this review.
\end{abstract}

\section{INTRODUCTION}

Inheritance is now recognized as an important factor in the occurrence of colorectal cancer. Approximately one-third of cases appear to have inheritance as a part of their pathogenesis [1](Figure 1). Three to five percent of colon cancers arise in the setting of an inherited syndrome where inherited susceptibility very penetrant. Extreme cancer risks are observed with malignancy often occurring at a young age. Up to a third of colon cancer cases exhibit a more moderate form of inheritance. In this setting familial clustering in excess of that expected by chance is often observed. The genes for this type of inheritance have not yet been identified, but numerous candidate genes have shown an association with colon cancer risk. Additionally, genetic-environment interactions are likely in this group. The remainder of colon malignancies appears to be associated with environmental factors, although polygenic susceptibility from one or multiple low penetrant genes could possibly also be present. Polygenic inheritance may not exhibit familial clustering clinically. This article will review familial risk and inherited susceptibility as presently understood for colon cancer.

\section{COMMON FAMILIAL RISK OF COLON CANCER}

A large twin study demonstrated that inherited factors account for $35 \%$ of colorectal cancer cases, while shared environmental factors accounted for 5\% and nonshared environmental factors the remaining $60 \%$ [2]. Only about $3 \%$ to $5 \%$ of inherited cases belong to one of the well-described inherited syndromes where inheritance is highly peneterant. The remainder of inherited or familial cases appears to arise from less penetrant factors.

Multiple studies indicate that if a person has a first-degree relative with colon cancer, the risk of this malignancy is two- to three-fold that expected in the general population [1,3,4]. If two first-degree relatives have colorectal cancer or a single first-degree relative is diagnosed at an age less than 50 years, the risk increases to 3 -fold or even greater. There is some increased risk even when second- or third-degree relatives have colon cancer, or a first-degree relative has a

Corresponding Author: Randall W. Burt, MD, University of Utah/Huntsman Cancer Institute, 2000 Circle of Hope, Salt Lake City, UT 84112-5550. E-mail: randall.burt@ hci.utah.edu, Telephone: 801-585-3281.

Publisher's Disclaimer: This is a PDF file of an unedited manuscript that has been accepted for publication. As a service to our customers we are providing this early version of the manuscript. The manuscript will undergo copyediting, typesetting, and review of the resulting proof before it is published in its final citable form. Please note that during the production process errors may be discovered which could affect the content, and all legal disclaimers that apply to the journal pertain. 
colonic adenomatous polyp [5,6]. Finally, age of diagnosis also influences the degree of risk. A colon cancer diagnosis in the ninth decade is associated with a 1.5-fold increased risk to first-degree relatives, while a diagnosis at an age less than 45 years correlates with a 4 -fold or greater risk [7].

Screening guidelines have been established for familial risk (Table 1) [1,8]. These guidelines are presently empiric based the observed risks. Approximately $7 \%$ of colon cancers occur at an age less than 50 years, while $20 \%$ occur as a part of a first-degree relative pair. This higher risk setting is thus not uncommon. As shown in Table 1, persons families with this level of risk should have colonoscopy as the preferred screening tool, beginning at age 40 or 10 years earlier than the youngest case in the family, and repeated every 5 years [1]. This risk level further indicates that a more extensive family history be taken for the possibility of one of the inherited syndromes. In such cases genetic testing may be indicated as outlined in the following sections.

\section{INHERITED SYNDROMES OF COLON CANCER}

\section{Familial Adenomatous Polyposis (FAP)}

FAP is an autosomal dominantly inherited condition arising from mutations of the adenomatous polyposis coli (APC) gene $[9,10]$ (Table 2). It is characterized by hundreds to thousands of colonic adenomatous polyps that begin to occur at an average age of 16 years. Colon cancer is inevitable if the colon is not removed. Seven percent of untreated individuals will have colon cancer by age 21 years, $50 \%$ by age 39 and $95 \%$ by age 50 . It is a relatively rare condition, affecting about one in 10,000 persons. Twenty percent to $30 \%$ of newly diagnosed cases not belonging to an established FAP family appear to represent a new mutation. But $50 \%$ of children, on average, will be affected, similar to established families.

Polyps are also found in the stomach, duodenum and small bowel, with a 50\%, 90\% and approximately $50 \%$ occurrence, respectively. Gastric polyps are fundic gland polyps with a less than $1 \%$ risk of malignancy. Duodenal polyps are adenomas and confer an approximate $5 \%$ life-time risk of cancer particularly in the peri-ampullary region. Although small bowel adenomas distal to the duodenum are common, as recently documented by capsule indoscopy, small bowel cancer past the duodenum is very unusual.

Associated benign extra-intestinal lesions include osteomas, epidermoid cysts and desmoid tumors, all occurring in about $20 \%$ of cases. Supernumerary teeth and congenital hypertrophy of the retinal pigment are also observed. When extra-intestinal lesions are prominent in a family, particularly osteomas and epidemoid cysts, the condition has historically been referred to as Gardner syndrome. Extra-intestinal cancers include an approximate 1\% to 2\% incidence of thyroid, pancreatic, CNS (meduloblastomas), liver and biliary tumors. Liver cancers are hepatoblastomas and occur mostly in the first five years of life. All other cancers virtually always occur at average ages older than colon cancer. Turcot syndrome has been defined as typical FAP with CNS tumors and is now clearly considered a subcategory of FAP.

An attenuated form of FAP is now recognized, called attenuated FAP [11-13]. It is characterized by fewer, more proximal colonic adenomas, but nonetheless a $70 \%$ to $80 \%$ lifetime risk of colon cancer. The emergence of polyps and cancer is delayed by about 10 years, and the number of colonic polyps is variable, even in the same family, from few polyps to hundreds. Extra-colonic manifestations of the disease appear to be similar to full-blown FAP. AFAP arises from mutations of the APC gene, although the mutations are usually found in the extreme proximal or distal portion of that gene. 
Screening recommendations for FAP are given in Table 2. Colectomy is performed when polyps become numerous or advanced but can often wait until after high school. About onethird of attenuated FAP patients can be managed without coloectomy. Endoscopic or surgical therapy for upper GI polyps is eventually needed in $10 \%$ to $20 \%$ of cases.

Genetic testing is used to confirm the diagnosis and should be considered in any person with 10 or more adenomas, in view of the attenuated form (Table 3) [14].

\section{MYH associated polyposis (MAP)}

MAP is a recently described syndrome phenotypically similar to attenuated FAP, but it arrises from biallelic mutations of the MYH gene, and is thus an autosomal recessive disease [15, 16]. It is found in about $10 \%$ of clinically diagnosed FAP cases where an APC mutation is not detected and in $10 \%$ to $40 \%$ of persons with 15 to 100 colonic adenomatous polyps. MAP accounts for approximately $0.5 \%$ of colon cancer cases overall, but $0.8 \%$ of those diagnosed under age 55 years $[17,18]$. Interestingly, one-third of colon cancer cases associated with MAP are found to have no adenomas.

Management of MAP should be similar to attenuated FAP (Table 2). Genetic testing is done for persons with $\geq 10$ colonic adenomas and should follow testing for FAP if no APC gene mutation is found (Table 3). When a recessive inheritance pattern is observed, one may begin with testing of the MYH gene.

\section{Hereditary Nonpolyposis Colorectal Cancer (HNPCC) or Lynch Syndrome}

HNPCC is an autosomal dominantly inherited condition that arises from mutations of one of four mismatch repair genes, MLH1, MSH2, MSH6 or PMS2 [19,20]. In 90\% or more of cases the mutation is found in one of the first two genes. In about 6\% of cases MSH6 mutations are found and only rarely do cases have PMS2 mutations. This syndrome is characterized by an autosomal dominant inheritance of colon cancer, but with only one or several adenomas. Neoplasms are more frequently found in the proximal colon. The average age of cancer diagnosis is 45 to 50 years, although it may be somewhat older. Frequent synchronous and metachronous cancers are found. HNPCC accounts for $1 \%$ to $3 \%$ of colon cancer cases.

Extra-colonic cancers are common in HNPCC including endometrial and ovarian cancer, with a $40 \%$ and an approximate $10 \%$ lifetime risk, respectively. There is also a $10 \%$ or less lifetime risk of gastric, urinary tract, renal, small bowel (particularly duodenal) and biliary cancers. There is a small risk of cutaneous keratocanthomas, a sebaceous gland tumor. The presence of this tumor in HNPCC defines the Muir-Torre syndrome. CNS glioblastomas may also rarely occur with HNPCC and when present define about one-third of cases of Turcot syndrome (the other two-thirds occur as a part of FAP).

HNPCC is clinically defined by the Amsterdam criteria I or II criteria, Table 4 [21]. If either of these criteria is met, one can proceed to genetic testing to detect a mutation in one of the mismatch repair genes [14]. This will be successful in 50\% to $70 \%$ of index cases. But approximately half of HNPCC cases and families will not be diagnosed by using only these criteria. Thus the Bethesda guidelines, also given in Table 4, have been developed to detect a greater proportion of cases. When any one of the Bethesda guidelines is met, the colon cancer tissue should be tested for micro-satellite instability (MSI) [22]. MSI is defined as frequent mutations in certain short DNA repeat segments called micro-satellites. MSI is present in almost all HNPCC associated colon cancers, but only in about $15 \%$ of sporadic colon cancers. An MSI positive tumor in a person meeting one of the Bethesda guidelines thus does not make a diagnosis of HNPCC, but indicates that germline genetic testing should be done. About $90 \%$ 
of HNPCC families who have an inherited mismatch repair mutation can be identified using this approach. If the tumor is MSI negative, HNPCC is extremely unlikely.

An alternative to MSI tumor testing is immunohistochemical (IHC) tumor testing. This is also applied when one of the Bethesda guidelines is met. IHC determines protein expression of the four HNPCC associated mismatch repair genes [14]. If one of the four is not expressed, mutation or dysfunction of that gene is inferred. Like MSI, an abnormal result indicates that germline genetic testing should be done. Also similar to MSI, almost all colon cancers in HNPCC exhibit lack of expression of one of the mismatch proteins, but about $15 \%$ of sporadic cancers also do. As IHC type testing can be done in most pathology laboratories, it is a more available test than MSI. It furthermore indicates which mismatch repair gene is mutated, limiting the genetic testing to that gene only.

Another approach to the diagnosis of HNPCC is the testing of all colon cancers for IHC abnormalities [23]. Ten percent to $15 \%$ of tumors will test positive, which would indicate that this approach would require this same fraction of colon cancer patients to undergo germline genetic testing. This is probably too large a testing burden, both for health systems and for the patients.

But the number of persons needing germline genetic testing can be decreased by a further method. Most of the sporadic colon cancers that have IHC abnormalities have them because of methylation of the promoter region of the MLH1 gene. BRAF tumor testing (for a specific single mutation in the BRAF gene) is a reliable marker of tumor hyper-methylation. Colon cancers from HNPCC patients virtually never exhibit a BRAF mutation, while $40 \%$ of sporadic tumors do.

To summarize this last approach, all colon cancers are tested for lack of expression of one of the mismatch repair genes. When such lack of expression is observed, tumor testing for the specific associated BRAF mutation follows. Only those without the BRAF mutation need undergo germline testing. In this way approximately $5 \%$ to $7 \%$ of persons with colon cancer will undergo germline genetic testing to find those with HNPCC. Several medical centers have already adopted this approach.

The genetic testing approaches to HNPCC are summarized in Figure 2 and Figure 3 and Table 3. Screening and surveillance guidelines are given in Table 2.

\section{The Hamartomatous Polyposis and Other Polyposis Syndromes of Colon Cancer}

The hamartomatous polyposis conditions include Peutz-Jeghers, juvenile polyposis and Cowden's syndromes [24,25]. Each of these three is extremely rare, occurring in between one in 100,000 and one in 200,000 persons. Each has a risk of colon and other cancers. Although hamartomatous polyps have been considered benign lesions, these polyps can develop areas of adenoma and cancer in the hamartoma syndromes. The resultant cancer risks are $42 \%, 50 \%$ and 9\% for Peutz-Jeghers, juvenile polyposis and Cowden syndromes, respectively. The phenotypes, cancer risks and surveillance for each of these are given in Table 2, and the genetic testing guidelines in Table 3 . Hereditary mixed polyposis syndrome is a rare condition that has now been described in a number of families [24]. Affected individuals exhibit numbers of adenomatous, juvenile and hyperplastic polyps. Colon cancer risk is increased and susceptibility loci have been demonstrated. Some families appear to be a variation of the juvenile polyposis syndrome. Hyperplastic polyposis is an increasingly recognized, but nonetheless rare polyposis syndrome [26]. It has been empirically defined by finding 20 or more colonic hyperplastic polyps scattered throughout the colon or multiple large hyperplastic polyps. There is an increased colon cancer risk, but familial occurrence is extremely rare. These last two syndromes are also summarized in Table 2 and Table 3. 


\section{CONCLUSIONS (2-500)}

Inheritance is a common factor in the pathogenesis of colon cancer. About one third of cases exhibit a moderately penetrant form of inherited predisposition, while $3 \%$ to $5 \%$ of cases occur as part of one of the rare but highly penetrant syndromes of colon cancer. The presence of any family history of colon cancer increases one's risk of this malignancy. Family history should thus always be taken into account in determining the most appropriate screening strategy for an individual and family. More aggressive screening is particularly indicated for persons with two first-degree relatives with colon cancer or a first-degree relative who has been diagnosed under the age of 50 years. An extended family history should be taken in this setting to see if the family has one of the rare inherited syndromes of colon cancer. A small fraction of those with a family history will be found to have one of these syndromes, where cancer risks are extreme and the age of cancer diagnosis can be very young. Genetic testing is now available for the diagnosis of most of these syndromes and should be considered when a strong family history of colon cancer is present or other indicative phenotypic features are found. The diagnosis of a specific syndrome indicates special screening and surveillance should be undertaken. This approach can prevent or detect early most cancers in both the setting of common familial risk and that of syndromic colon cancer, emphasizing the need for careful family history in families where colon cancer is observed.

\section{Acknowledgements}

This work was supported by grants from the National Cancer Institute: R01-CA40641 and PO1-CA73992. Additional support was provided by a Cancer Center Support Grant P30-CA42014 and the Huntsman Cancer Foundation.

\section{REFERENCES}

1. Burt RW. Colon cancer screening. Gastroenterology 2000;119(3):837-853. [PubMed: 10982778]

2. Lichtenstein $P$, et al. Environmental and heritable factors in the causation of cancer. New England Journal of Medicine 2000;343:78-85. [PubMed: 10891514]

3. Johns LE, Houlston RS. A systematic review and meta-analysis of familial colorectal cancer risk. Am J Gastroenterol 2001;96(10):2992-3003. [PubMed: 11693338]

4. Hemminki K, Granstrom C, Chen B. The Swedish Family-Cancer Database: update, application to colorectal cancer and clinical relevance. Hereditary Cancer in Clinical Practice 2005;3(1):7-18.

5. Slattery ML, Kerber RA. Family history of cancer and colon cancer risk: the Utah population database. Journal of the National Cancer Institute 1994;86:1618-1626. [PubMed: 7932826]

6. Winawer SJ, et al. Risk of colorectal cancer in the families of patients with adenomatous polyps. National Polyp Study Workgroup. N Engl J Med 1996;334(2):82-87. [PubMed: 8531963]

7. St John DJ, et al. Cancer risk in relatives of patients with common colorectal cancer. Ann Intern Med 1993;118(10):785-790. [PubMed: 8470852]

8. Winawer $\mathrm{S}$, et al. Colorectal cancer screening and surveillance: Clinical guidelines and rationaleUpdate based on new evidence. Gastroenterology 2003;124(2):544-560. [PubMed: 12557158]

9. Galiatsatos P, Foulkes WD. Familial adenomatous polyposis. Am J Gastroenterol 2006;101(2):385398. [PubMed: 16454848]

10. Burt, RW.; Jacoby, RF. Polyposis Syndromes. In: Yamada, T., editor. Textbook of Gastroenterology. 4th Edition. New York: Lippincott Williams \& Wilkins; 2003. p. 1914-1939.

11. Burt RW, et al. Genetic testing and phenotype in a large kindred with attenuated familial adenomatous polyposis. Gastroenterology 2004;127(2):444-451. [PubMed: 15300576]

12. Knudsen AL, Bisgaard ML, Bulow S. Attenuated familial adenomatous polyposis (AFAP). A review of the literature. Fam Cancer 2003;2(1):43-55. [PubMed: 14574166]

13. Hernegger GS, Moore HG, Guillem JG. Attenuated familial adenomatous polyposis: an evolving and poorly understood entity. Dis Colon Rectum 2002;45(1):127-134. [PubMed: 11786778]discussion $134-6$ 
14. Burt R, Neklason DW. Genetic testing for inherited colon cancer. Gastroenterology 2005;128(6): 1696-1716. [PubMed: 15887160]

15. Sieber OM, et al. Multiple colorectal adenomas, classic adenomatous polyposis, and germ-line mutations in MYH. N Engl J Med 2003;348(9):791-799. [PubMed: 12606733]

16. Wang $\mathrm{L}$, et al. MYH mutations in patients with attenuated and classic polyposis and with young-onset colorectal cancer without polyps. Gastroenterology 2004;127(1):9-16. [PubMed: 15236166]

17. Fleischmann $\mathrm{C}$, et al. Comprehensive analysis of the contribution of germline MYH variation to earlyonset colorectal cancer. Int J Cancer 2004;109(4):554-558. [PubMed: 14991577]

18. Balaguer F, et al. Identification of MYH mutation carriers in colorectal cancer: a multicenter, casecontrol, population-based study. Clin Gastroenterol Hepatol 2007;5(3):379-387. [PubMed: 17368238]

19. Lynch HT, de la Chapelle A. Hereditary colorectal cancer. N Engl J Med 2003;348(10):919-932. [PubMed: 12621137]

20. Vasen HF, et al. Guidelines for the clinical management of Lynch syndrome (hereditary non-polyposis cancer). J Med Genet 2007;44(6):353-362. [PubMed: 17327285]

21. Vasen HFA, et al. New clinical criteria for hereditary nonpolyposis colorectal cancer (HNPCC, Lynch syndrome) proposed by the International Collaborative Group on HNPCC. Gastroenterology 1999;116:1453-1456. [PubMed: 10348829]

22. Umar A, et al. Revised Bethesda guidelines for hereditary nonpolyposis colorectal cancer (Lynch syndrome) and microsatellite instability. Journal of the National Cancer Institute 2004;96:261-268. [PubMed: 14970275]

23. Hampel H, et al. Screening for the Lynch syndrome (hereditary nonpolyposis colorectal cancer). N Engl J Med 2005;352(18):1851-1860. [PubMed: 15872200]

24. Schreibman IR, et al. The hamartomatous polyposis syndromes: a clinical and molecular review. Am J Gastroenterol 2005;100(2):476-490. [PubMed: 15667510]

25. Zbuk KM, Eng C. Hamartomatous polyposis syndromes. Nat Clin Pract Gastroenterol Hepatol 2007;4 (9):492-502. [PubMed: 17768394]

26. Chow E, et al. Hyperplastic polyposis syndrome: phenotypic presentations and the role of MBD4 and MYH. Gastroenterology 2006;131(1):30-39. [PubMed: 16831587]

27. Umar A, et al. Testing guidelines for hereditary non-polyposis colorectal cancer. Nat Rev Cancer 2004;4(2):153-158. [PubMed: 14964310] 


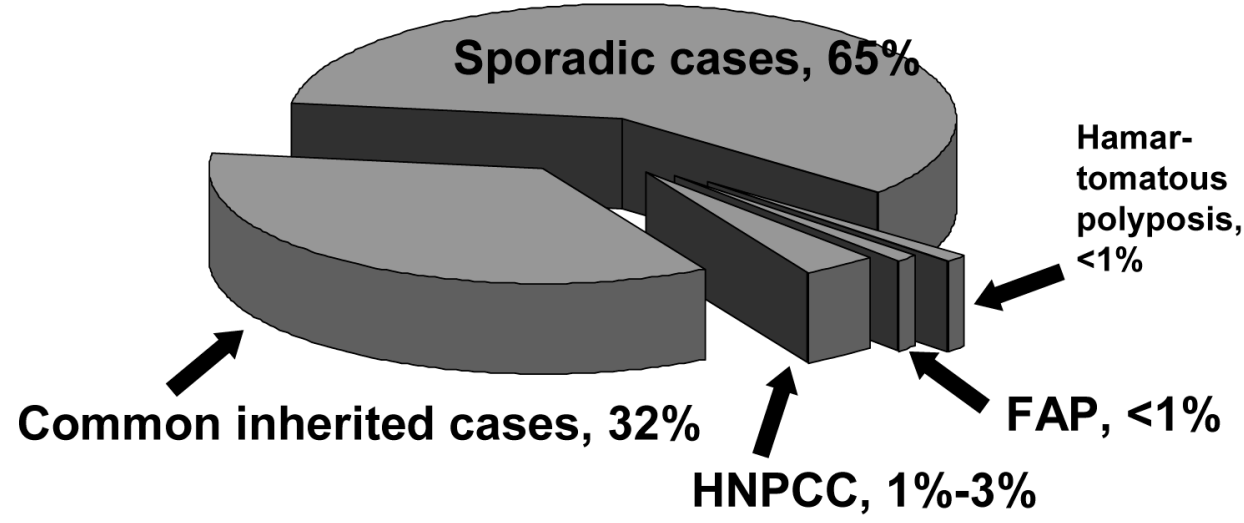

Figure 1. Causes of Colon Cancer

The majority of colon cancers are thought to arise from environmental factors and are called sporadic. Approximately one-third arise from moderately penetrant inherited susceptibility, possibly interacting with environmental factors. The genes involved in this type of inheritance have not yet been defined, although a number of candidate genes have been suggested. Up to $3 \%$ of colon cancer cases arise in the setting of inherited syndromes, where the risk of colon cancer is very high. These include hereditary nonpolypsis colon cancer (HNPCC), familial adenomatous polyposis (FAP) and several extremely rare hamartomatous polyposis syndromes (see table 2 and table 3). (Modified from Burt, 2000 [1]. 


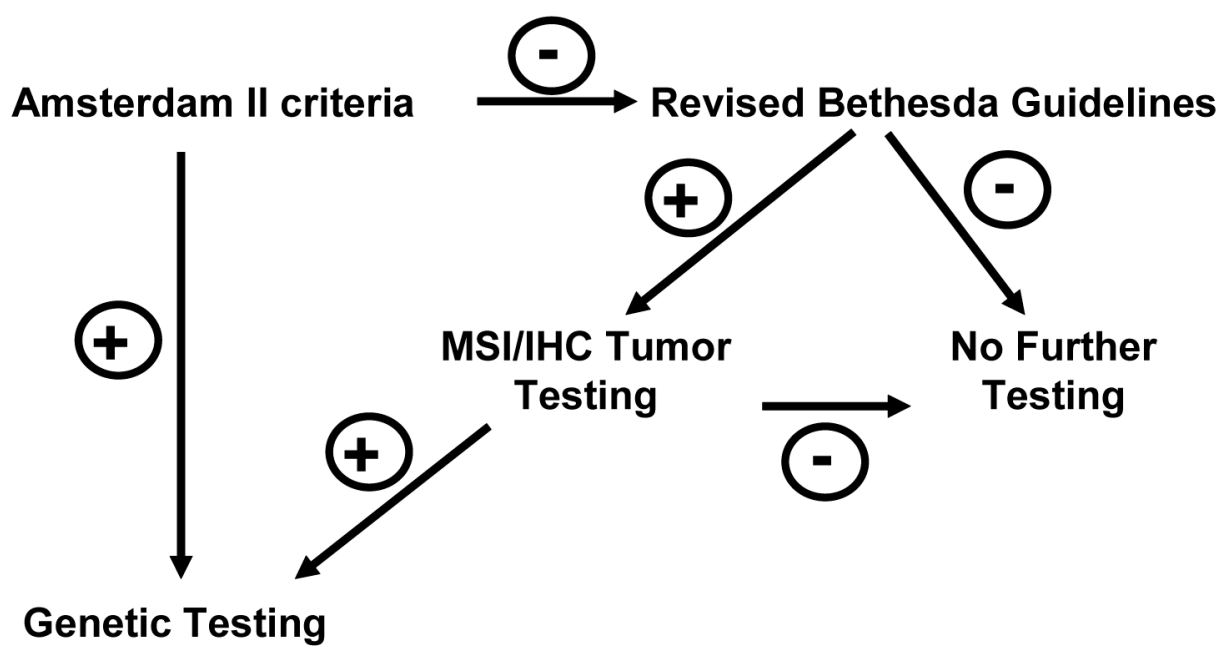

Figure 2. Genetic Testing Approach for Lynch Syndrome

There are several approaches to determine who should have genetic testing for hereditary nonpolyposis colorectal cancer (HNPCC) or Lynch syndrome. If Amsterdam II criteria are met (see Table 4), one may proceed directly to germline genetic testing. If there is a strong family history of colon cancer, but these criteria are not met, the Bethesda Guidelines should be applied. If any of these are met, the tumor should be tested for microsatellite (MSI) instability and/or tumor immunochemistry (IHC) should be done. IHC examines the expression of the mismatch repair genes. If MSI is positive or IHC testing indicates lack of expression of one of the mismatch repair proteins, then one should proceed to germline genetic testing. This testing usually involves a peripheral blood draw and lymphocyte DNA for the testing. (Modified from [27] 


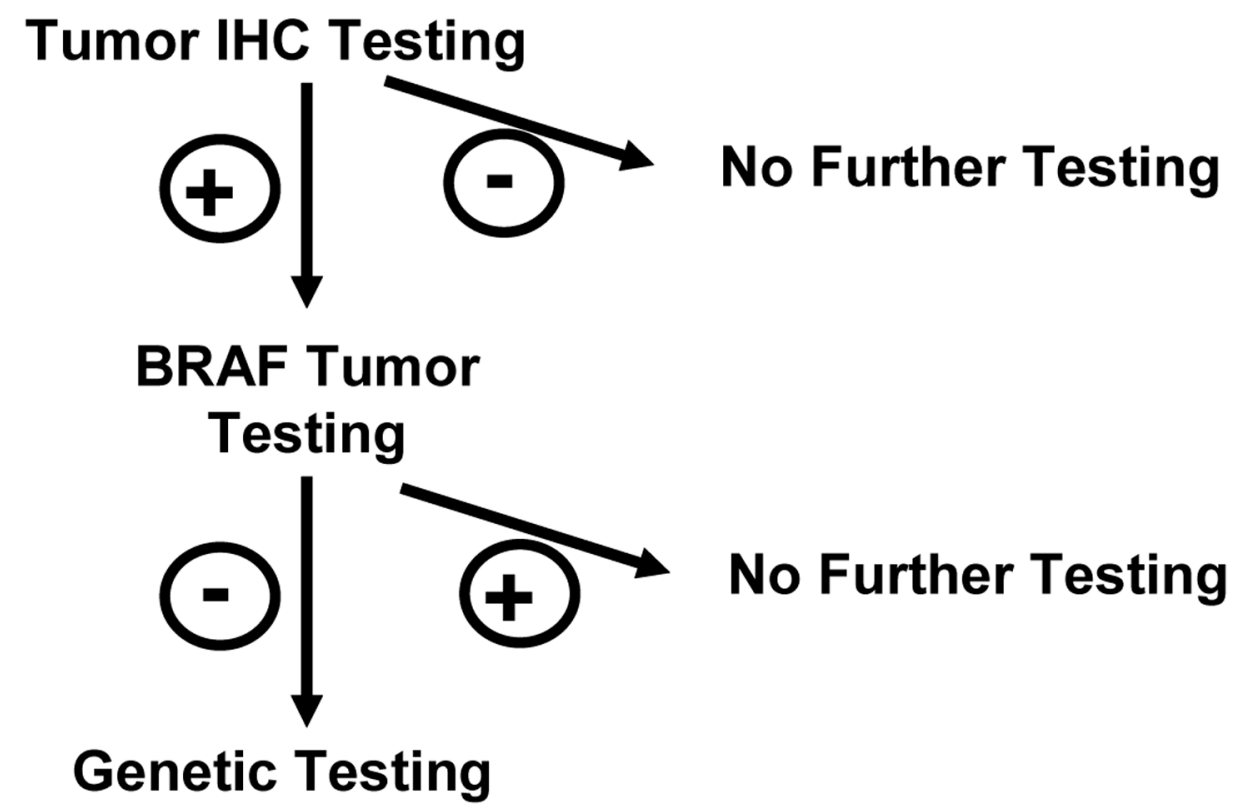

Figure 3. Testing All Colon Cancers as an Approach to Lynch Syndrome

Another approach to genetic testing for HNPCC or Lynch syndrome begins with testing all colon cancers by immunohistochemical methods looking for expression of one of the mismatch repair genes. Ten percent to $15 \%$ of tumors will show lack of expression although only $1 \%$ to $3 \%$ of tumors will actually be from patients with Lynch syndrome. Testing the tumor for a specific BRAF mutation can eliminate about half of the sporadic tumors, substantially decreasing the number of persons that should then undergo germline genetic testing. 
Table 1

Colon Cancer Screening Guidelines Based on Familial Risk

\begin{tabular}{|c|c|c|}
\hline Setting & Lifetime Colon Cancer Risk & Screening Recommendations \\
\hline $\begin{array}{l}\text { Average risk (no family history } \\
\text { of }^{C R C^{l}} \text { ) }\end{array}$ & $6 \%$ & $\begin{array}{l}\text { Begin at age } 50 \text { years with any one of the following: } \\
\text { FOBT } 2 \text { annually } \\
\text { Sigmoidoscopy every } 5 \text { years } \\
\text { Both of the above } \\
\text { Barium enema every } 5 \text { years } \\
\text { Colonoscopy every } 10 \text { years }\end{array}$ \\
\hline $\begin{array}{l}\text { One first-degree relative }{ }^{3} \text { with } \\
\mathrm{CRC}^{1} \text { at }>50 \text { years }\end{array}$ & 2- to 3-fold increased & Same as for average risk, but begin at age 40 years \\
\hline $\begin{array}{l}\text { One first-degree relative }{ }^{3} \text { with } \\
\text { CRC }^{1}<50 \text { years }\end{array}$ & 3- to 4-fold increased & $\begin{array}{l}\text { Colonoscopy every } 5 \text { years starting at age } 40 \text { years or } 10 \text { years earlier than } \\
\text { the age of diagnosis in the relative, whichever comes first }\end{array}$ \\
\hline $\begin{array}{l}\text { Two first-degree relatives }{ }^{3} \text { with } \\
\text { CRC }^{l}\end{array}$ & 3- to 4-fold increased & $\begin{array}{l}\text { Colonoscopy every } 5 \text { years starting at age } 40 \text { years or } 10 \text { years earlier than } \\
\text { the youngest case, whichever comes first }\end{array}$ \\
\hline $\begin{array}{l}\text { Second }{ }^{4} \text { - or third-degree } \\
\text { relatives with CRC }^{1}\end{array}$ & 1.5 -fold increased & Same as average risk screening \\
\hline $\begin{array}{l}\text { First-degree relative }{ }^{3} \text { with } \\
\text { adenomatous polyp }\end{array}$ & About 2-fold increased & $\begin{array}{l}\text { Same as average risk, but consider starting at age } 40 \text { years, especially if } \\
\text { the adenoma is advanced } 6\end{array}$ \\
\hline \multicolumn{3}{|l|}{${ }^{1}$ CRC: colorectal cancer } \\
\hline \multicolumn{3}{|l|}{${ }^{2}$ FOBT: fecal occult blood test } \\
\hline \multicolumn{3}{|c|}{${ }^{3}$ First-degree relative: parent, sibling or child } \\
\hline \multicolumn{3}{|c|}{${ }^{4}$ Second-degree relative: grandparent, aunt or uncle } \\
\hline 5 Third-degree relative: great gl & $\mathrm{t}$, cousin & \\
\hline
\end{tabular}


Table 2

Colorectal Cancer Syndromes, Phenotype, Surveillance and Treatment

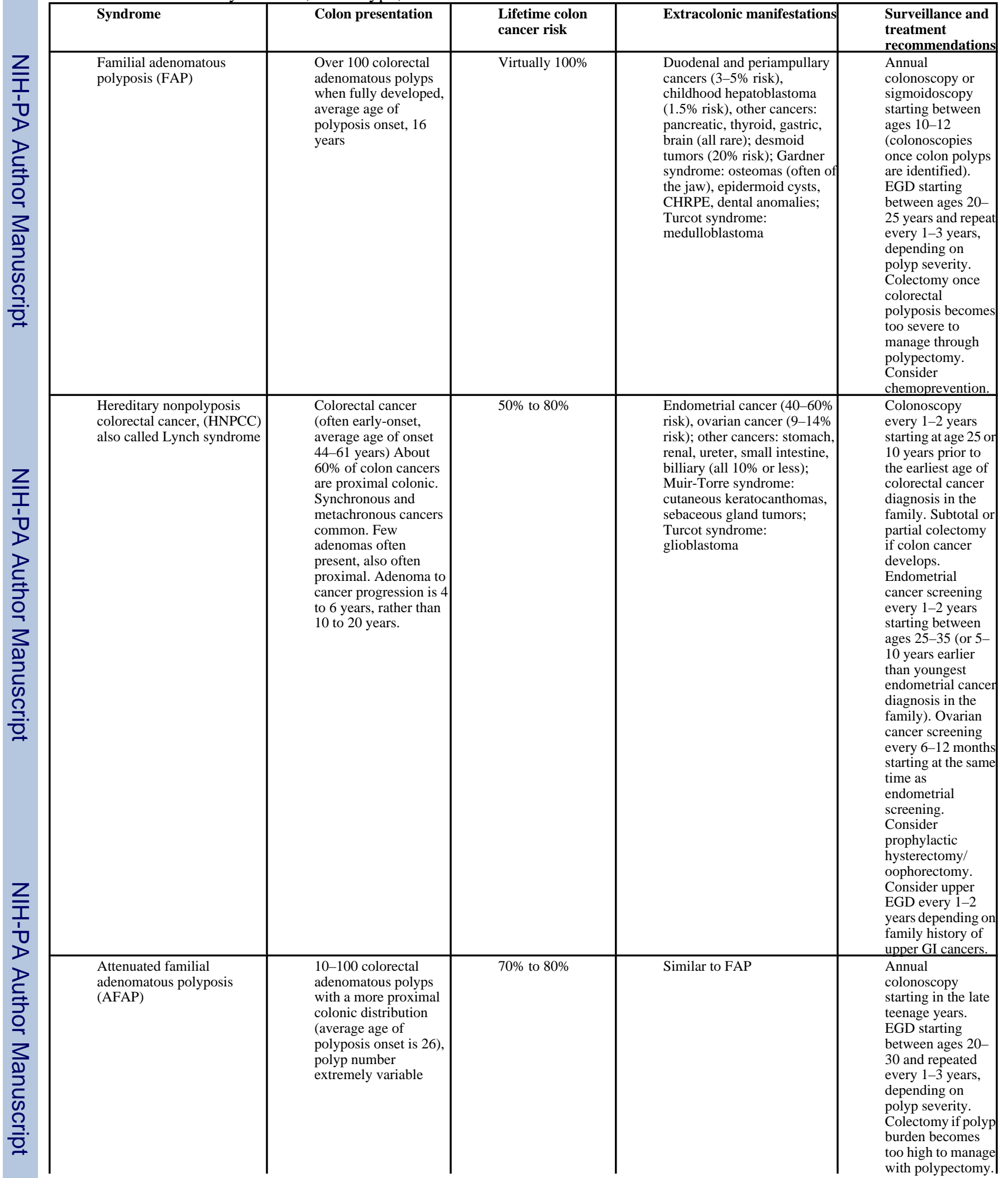




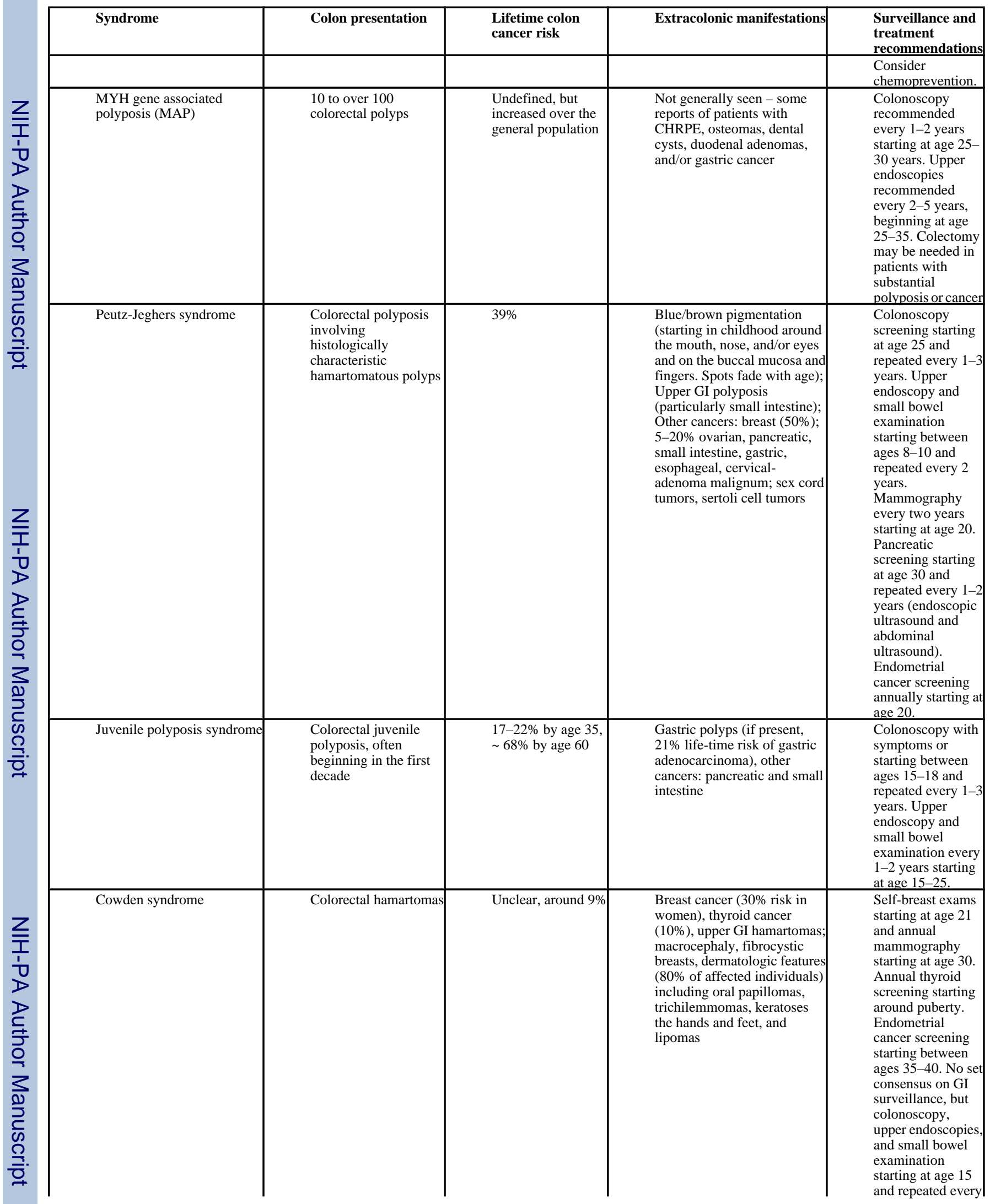




\begin{tabular}{|c|c|c|c|c|}
\hline Syndrome & Colon presentation & $\begin{array}{l}\text { Lifetime colon } \\
\text { cancer risk }\end{array}$ & Extracolonic manifestations & $\begin{array}{l}\text { Surveillance and } \\
\text { treatment } \\
\text { recommendations }\end{array}$ \\
\hline & & & & $\begin{array}{l}2 \text { years would } \\
\text { seem reasonable }\end{array}$ \\
\hline Hyperplastic polyposis & $\begin{array}{l}\text { Colorectal polyposis } \\
\text { featuring }>20 \text { small or } \\
\geq 2 \text { or more large } \\
\text { hyperplastic polyps } \\
(\geq 1 \mathrm{~cm}) \text { and some } \\
\text { adenomas } / \text { serrated } \\
\text { adenomas }\end{array}$ & Undefined & None reported & $\begin{array}{l}\text { No set consensus - } \\
\text { consider } \\
\text { colonoscopy every } \\
1-3 \text { years } \\
\text { depending on } \\
\text { patient's level of } \\
\text { polyposis. } \\
\text { Colectomy may be } \\
\text { needed when } \\
\text { polyps can no } \\
\text { longer be managed } \\
\text { with } \\
\text { colonoscopically. }\end{array}$ \\
\hline
\end{tabular}


Table 3

Syndrome Genetic Testing and Indications for Genetic Testing

\begin{tabular}{|c|c|c|c|}
\hline Syndrome & Involved Gene(s) & $\begin{array}{l}\text { Indication to perform genetic } \\
\text { testing }\end{array}$ & $\begin{array}{l}\text { Frequency of identifying } \\
\text { a genetic mutation in an } \\
\text { index case }\end{array}$ \\
\hline $\begin{array}{l}\text { Familial adenmoatous polyposis } \\
\text { (FAP) and attenuated FAP (AFAP) }\end{array}$ & APC & $\begin{array}{l}\geq 10 \text { colonic adenomas, } \geq 5 \\
\text { adenomas with suggestive family } \\
\text { history }\end{array}$ & $80 \%$ to $90 \%$ \\
\hline $\begin{array}{l}\text { Hereditary nonpolyposis colorectal } \\
\text { cancer (HNPCC) or Lynch syndrome }\end{array}$ & MLH1, MSH2, MSH6, PMS2 & $\begin{array}{l}\text { Positive Amsterdam criteria or } \\
\text { Bethesda guidelines, see also text } \\
\text { and Figure } 1\end{array}$ & $50 \%$ to $70 \%$ \\
\hline $\begin{array}{l}\text { MYH gene associated polyposis } \\
\text { (MAP) }\end{array}$ & MYH & Same as FAP and AFAP & $\begin{array}{l}\text { MYH gene mutation } \\
\text { found in } 10 \% \text { to } 15 \% \text { of } \\
\text { FAP families not found to } \\
\text { have APC mutations, and } \\
\text { found in } 10 \% \text { to } 40 \% \text { of } \\
\text { persons with } 15 \text { to } 100 \\
\text { colorectal adenomas }\end{array}$ \\
\hline Peutz-Jeghers syndrome (PJS) & STK11 & $\begin{array}{l}\text { Histologically typical } \\
\text { gastrointestinal polyps or typical } \\
\text { oral or facial pigmentation }\end{array}$ & $90 \%$ to near $100 \%$ \\
\hline Juvenile polyposis syndrome (JPS) & BMPR1A, SMAD4, ENG & $\geq 3$ juvenile polyps & $\begin{array}{l}\text { About } 20 \% \text { of JPS is } \\
\text { caused by BMPR } 1 \mathrm{~A} \\
\text { mutations, about } 20 \% \text { by } \\
\text { SMAD } 4 \text { mutations, and } \\
\text { ENG mutation families are } \\
\text { rare }\end{array}$ \\
\hline Cowden syndrome (CS) & PTEN & $\begin{array}{l}\text { Typical skin findings or finding } \\
\text { gastrointestinal juvenile polyps } \\
\text { but not JPS, see Table } 2\end{array}$ & $50 \%$ to $90 \%$ \\
\hline $\begin{array}{l}\text { Hereditary mixed polyposis syndrome } \\
\text { (HMPS) }\end{array}$ & $\begin{array}{l}\text { Candidate locus at } 15 \mathrm{q} 13- \\
\text { 14: ?BMPR1A }\end{array}$ & $\begin{array}{l}\text { Mixed histology colonic } \\
\text { polyposis }\end{array}$ & N/A \\
\hline $\begin{array}{l}\text { Hyperplastic polyposis syndrome } \\
\text { (HPS) }\end{array}$ & Unknown, rarely familial & $\begin{array}{l}>20 \text { colonic hyperplastic polyps, } \\
\text { or } \geq \text { larger hyperplastic polyps } \\
(\geq 1 \mathrm{~cm})\end{array}$ & N/A \\
\hline
\end{tabular}

NOTE: accuracy of mutation specific genetic testing for other family members, once a mutation has been identified in the index, case is near $100 \%$ 
Table 4

Amsterdam Criteria and Bethesda Guidelines

Amsterdam Criteria (for clinical identification of HNPCC and to determine families that should undergo germline genetic testing)

At least 3 relatives with colorectal cancer plus all of the following:

1 One affected patient is a first-degree relative of the other two

2 Two or more successive generations affected

3 One or more affected relative received colorectal cancer diagnosis at age $<50$ years

$4 \quad$ FAP excluded

5 Tumors verified by pathologic examination

Amsterdam II Criteria

Same as original Amsterdam criteria, except extra-colonic cancers added to the positive phenotype. These classically include: cancers of the endometrium, small bowel, ureter, and renal pelvis, but other associated cancers are often also included such as renal, gastric and possibly pancreatic.

Bethesda Guidelines (for identification of patients who should have colon cancer tissue testing for microsatellite instability and/or immunohistochemistry to examine protein expression of the mismatch repair genes)

1 Individuals with cancer in families that meet the Amsterdam Criteria

2 Individuals with 2 Lynch syndrome related cancers, including synchronous and metachronous colorectal cancer or associated extracolonic cancer (endometrium, ovarian, gastric, hepatobiliary, or small-bowel cancer or transitional-cell carcinoma of the renal pelvis or ureter)

3 Individuals with colorectal cancer and a first-degree relative with colorectal cancer or Lynch syndrome related extracolonic cancer or a colorectal adenoma; one of the cancers diagnosed at age $<45$ years, ${ }^{1}$ and the adenoma diagnosed $<40$ years

4 Individuals with colorectal cancer or endometrial cancer diagnosed at age $<45$ years 1

5 Individuals with right-sided colorectal cancer with an undifferentiated pattern (solid, cribriform), defined as poorly differentiated or undifferentiated carcinoma composed of irregular, solid sheets of large eosinophilic cells and containing small gland-like spaces

6 Individuals with signet-ring-cell type colorectal cancer diagnosed at age $<45$ years ${ }^{1}$ (composed of $>50 \%$ signet-ring cells)

7 Individuals with adenomas diagnosed at age $<40$ years

1 Modified Bethesda criteria replace the age of " $<45$ " for colorectal cancer diagnosis with " $<50$." 